\title{
DUKUNGAN SOSIAL DAN TINGKAT STRES PADA IBU PASCA MELAHIRKAN ANAK PERTAMA
}

Annisa Fitriani ${ }^{1}$, Indar Nuryati ${ }^{2}$

1,2Program Studi Psikologi Islam Fakultas Usluhuddin dan Studi Agama UIN Raden Intan Lampung, email: annisa.fitriani@radenintan.ac.id; indarnuryati@gmail.com

\section{ABSTRACT: SOCIAL SUPPORT AND STRESS LEVEL AMONG POST FIRST DELIVERY MOTHERS}

Mothers who experienced stress after giving birth tend to have difficulties in self adjustment, even more so among first delivery mothers. Social support is needed to help mothers cope with stress after delivery. This study was aim to identified the relationship between social support and stress lebel in mothers post first born delivery. The sample of this study was 31 mothers in Desa Tamansari, Gedongtataan, Pesawaran. Measurement tool used to obtain data was social support and stress scale. In this study, the relationship between social support and stress was analysed by pearson correlation. The result of this study shows no significant correlation between social support and stress level $(r(31)=.238$ dengan $p>.05$ ). Based on the result of this study, a further research need to be conducted to analyse the other factors, beside social support, that relate with stress level among post first delivery mothers

\section{Keywords: Social Support, Stress Level, Knowledge, Mothers, Post First Delivery}

Ibu yang mengalami stres setelah melahirkan cenderung mengalami kesulitan dalam penyesuaian diri, terlebih pada kelahiran anak pertama. Dukungan sosial diperlukan untuk membantu ibu mengatasi stress yang dialami setelah persalinan. Penelitian ini bertujuan untuk mengetahui hubungan dukungan sosial dengan tingkat stres pada ibu pasca melahirkan anak pertama. Sampel penelitian ini berjumlah 31 orang Ibu di Desa Tamansari Kecamatan Gedongtataan Kabupaten Pesawaran. Alat ukur yang digunakan untuk pengumpulan data adalah skala dukungan sosial dan skala tingkat stress. Dalam penelitian ini hubungan dukungan sosial dengan tingkat stress diuji dengan korelasi Pearson. Hasil penelitian menunjukan tidak ada hubungan antara dukungan sosial dengan tingkat stress $(r(31)=.238$ dengan $p>$.05). Berdasarkan hasil penelitian perlu dilakukan studi lebih lanjut mengenai faktor-faktor lain selain dukungan sosial yang berhubungan dengan tingkat stress ibu setelah melahirkan anak pertama.

Kata kunci: Dukungan Sosial, Tingkat Stres, Pengetahuan, Ibu, Pasca Melahirkan Anak Pertama

\section{PENDAHULUAN}

Kehamilan pada umumnya

memberikan arti emosional yang sangat besar

pada setiap wanita karena kehamilan merupakan salah satu ekspresi perwujudan diri dan perwujudan identitas sebagai calon ibu. Kehamilan juga merupakan kebanggaan tersendiri bagi wanita untuk mewujudkan feminisme, dan untuk menunjukkan jati diri seorang wanita tersebut. Proses kehamilan pada umumnya mendatangkan suatu kebahagiaan tersendiri bagi wanita, walaupun kehamilan tersebut mengandung resiko mempertaruhkan jiwa dan raga, khususnya pada saat melahirkan bayinya. Persalinan merupakan saat yang sangat dinanti-nantikan oleh ibu hamil, terutama primigravida (kehamilan pertama) untuk segera dapat merasakan kebahagiaan melihat dan memeluk bayi yang telah dikandungnya selama berbulan-bulan. 


\section{DUKUNGAN SOSIAL DAN TINGKAT STRES PADA IBU PASCA MELAHIRKAN ANAK PERTAMA}

Disisi lain dalam persalinan sendiri sering terdapat hambatan-hambatan yang dapat berisiko buruk bagi ibu maupun bayinya. Ibu hamil, terutama pada kehamilan pertama dapat mengalami berbagai perasaan yang bercampur aduk. Selain perasaan bahagia yang tidak terlukiskan, juga kecemasan, kekhawatiran, takut karena ia belum pernah mengalami proses tersebut. Menghadapi kelahiran bayi merupakan pengalaman konkret yang dapat menimbulkan kondisi psikologis tidak stabil pada perempuan hamil pertama, misalnya: perasaan tegang, khawatir atau takut (Bobak, Lowdermilk \& Jensen, 2005).

Persalinan pertama adalah proses melahirkan anak pertama bagi ibu. Ibu yang melahirkan anak pertama ini sering disebut sebagai ibu primipara, wanita yang baru pertama kali mempunyai anak dan baru menjadi ibu (Bobak, Lowdermilk \& Jensen, 2005). Belum adanya pengalaman yang dialami oleh ibu yang baru pertama kali melahirkan terkadang dapat menimbulkan masalah-masalah yang mana dapat mengakibatkan kesulitan dalam menyesuaikan peran baru. Hal tersebut apabila dibiarkan saja maka dapat mengakibatkan sebagian ibu mengalami stres pasca melahirkan (Hidayati, 2009).

Stress atau perasaan tertekan dapat mempengaruhi dan merugikan bayi lewat perubahan fisik yang terjadi pada ibu hamil.
Seperti peningkatan detak jantung dan peningkatan hormon stress. Stress psikologis memiliki efek fisik kuat pada persalinan. Hormon stress, seperti adrenalin berinteraksi dengan reseptor - beta di dalam otot uterus dan menghambat kontraksi, memperlambat persalinan (Cluctt, 2000).

Pada ibu hamil yang mempunyai tingkat stress yang tinggi dapat meningkatkan resiko kelahiran bayi prematur bahkan keguguran. Ibu yang mengalami stress mungkin mengalami tekanan yang sangat berat saat melahirkan. Faktor lainnya yaitu karena proses persalinan yang membuat trauma dan kurangnya dukungan pada saat kehamilan dan persalinan. Perasaan belum siap menjadi ibu, misalnya karena usia terlalu muda. (Indiarti, 2004)

Pada beberapa wanita, kehamilan pertama juga menimbulkan hal-hal yang berbeda yang tidak dirasakan oleh wanita lainnya secara umum. Pada beberapa wanita kehamilan pertama dapat menjadi suatu beban dan rasa terbuang karena tidak dapat melakukan aktivitas keseharian seperti biasa sebelum adanya kehamilan. Dalam beberapa kasus terjadi wanita yang merasa dirinya terbuang dan disisihkan dari pergaulan dan hal tersebut akan menimbulkan tekanan secara psikologis yang dapat menimbulkan stress pada wanita (Aprianawati dan Sulistyorini, 2007).

Anisa Fitriani, Program Studi Psikologi Islam, Fakultas Usluhuddin dan Studi Agama UIN Raden Intan Lampung. Email: anisa.fitriani@radenintan.ac.id

Indar Nuryati, Program Studi Psikologi Islam, Fakultas Usluhuddin dan Studi Agama UIN Raden Intan Lampung. Email: indar,nuryati@gmail.com 


\section{DUKUNGAN SOSIAL DAN TINGKAT STRES PADA IBU PASCA MELAHIRKAN ANAK PERTAMA}

Berdasarakan survei LSI, diketahui bahwa dari 100 orang ibu yang mengalami kehamilan untuk pertama kali, terdapat sekitar 52 orang yang mengalami kecemasan dan gangguan psikologis yang disebabkan oleh ketidaktahuan mereka akan kondisi sedang dialami (Tongko, 2018). Ketidaktahuan akan kondisi yang sedang mereka alami tersebut akan menyebabkan penanganan yang salah dalam menyikapi masa kehamilan untuk pertama kalinya. Berdasarkan data dari Klinik Bersalin Nurul Trisulo di Bekonang tahun 2011 pada bulan DesemberFebruari 2011 sejumlah 16 ibu hamil, enam diantaranya ibu hamil kehamilan pertama dengan usia kehamilan sama yaitu sembilan bulan atau masa dimana akan menghadapi persalinan mengalami cemas bahkan stress. Berdasarkan fenomena yang terjadi saat peneliti melakukan wawancara pada tanggal 04 Desember 2018 di Desa Bangun Harjo Pesawaran ditemukan seorang ibu muda yang berinisial SA (23 tahun) yang memilik bayi berumur 2 minggu yang mengatakan bahwa dia sempat merasa takut, cemas, kemudian tidak nafsu makan, tak jarang juga mengalami emosi yang kurang stabil akibat dari penyesuaian terhadap peran barunya sebagai ibu. SA mengaku sangat membutuhkan perhatian dan dukungan dari keluarga. Dukungan dari keluarga adalah salah satu bentuk dukungan sosial. Dukungan sosial merupakan salah satu faktor yang sangat berpengaruh terhadapmunculnya stres pasca melahirkan dan bahkan dapat menurunkan angka peluang munculnya gangguan tersebut. Smet (1994) menjelaskan bahwa dukungan sosial ialah usaha untuk memberikan pertolongan kepada seseorang dengan tujuan untuk meningkatkan kualitas kesehatan mental, memberikan rasa percaya, nasihat, dorongan atau semangat dan penerimaan. Dukungan sosial kepada wanita yang mengalami stress pasca melahirkan dapat diberikan oleh orang-orang terdekat, seperti keluarga, sahabat, rekan kerja,.

Dukungan keluarga yang diberikan kepada ibu hamil dapat berupa persiapan dalam masa kehamilan. Selama ibu hamil mempersiapkan kelahiran membutuhkan dukungan dari suami dan anggota keluarga termasuk faktor eksternal, sehingga dapat memberikan ketenangan batin kepada ibu hamil. Ketenangan batin ibu hamil mempengaruhi kenyamanan dan kesiapan ibu hamil termasuk faktor internal, sehingga ibu hamil tidak mengalami kecemasan. Pernyataan tersebut dijelaskan oleh Sarason (dalam Sarafino, 2008) bahwa dukungan sosial keluarga memiliki peranan penting untuk mencegah individu mengalami ancaman kesehatan mental. Individu yang memiliki dukungan sosial yang lebih kecil, lebih memungkinkan mengalami konsekuensi psikis yang negatif. Keuntungan individu yang

Anisa Fitriani, Program Studi Psikologi Islam, Fakultas Usluhuddin dan Studi Agama UIN Raden Intan Lampung. Email: anisa.fitriani@radenintan.ac.id

Indar Nuryati, Program Studi Psikologi Islam, Fakultas Usluhuddin dan Studi Agama UIN Raden Intan Lampung. Email: indar,nuryati@gmail.com 


\section{DUKUNGAN SOSIAL DAN TINGKAT STRES PADA IBU PASCA MELAHIRKAN ANAK PERTAMA}

memperoleh dukungan sosial yang tinggi akan menjadi individu lebih optimis dalam menghadapi kehidupan saat ini maupun masa yang akan datang, lebih terampil dalam memenuhi kebutuhan psikologi dan memiliki sistem yang lebih tinggi, serta tingkat kecemasan yang lebih rendah, mempertinggi interpersonal skill (keterampilan interpersonal), memiliki kemampuan untuk mencapai apa yang diinginkan dan lebih dapat membimbing individu untuk beradaptasi dengan stres atau kecemasan.

Berdasarkan paparan diatas peneliti mengemukakan bahwa salah satu yang dapat mengurangi stres adalah dukungan sosial, yang dapat diperoleh dari keluarga dan lingkungan tempat ibu tersebut tinggal dampak dari dukungan sosial tersebut sangat membantu ibu berada pada emosi stabil sehingga tidak mengalami stres.

Menurut Sulistyawati ( 2010) terdapat efek tidak langsung dari dukungan sosial berarti dukungan sosial mempengaruhi kesejahteraan individu dengan mengurangi tingkat keparahan stres dari suatu peristiwa. Dukungan sosial ini dapat diperoleh dari sejumlah orang yang dianggap penting (significant others) seperti suami, anak, orang tua, saudara atau kerabat dan teman akrab (Kumolohadi, 2001).

Berdasarkan latar belakang permasalahan di atas bahwasanya wanita yang melahirkan anak pertama cenderung memiliki tingkat stres yang tinggi sehingga membutuhkan dukungan sosial baik dari keluarga, lingkungan, maupun teman sebaya. Oleh karena itu, peneliti tertarik untuk meneliti apakah ada hubungan antara dukungan sosial dengan tingkat stres pada wanita pasca melahirkan anak pertama.

\section{METODE}

Penelitian ini menggunakan metode penelitian kuantitaif. Sampel dalam penelitian berjumalh 31 ibu baru pertama kali melahirkan yang berada di Desa Taman Sari Kecamatan Gedong Tataan Kabupaten Pesawaran. Sampel diperoleh menggunakan teknik purposive sampling, dengan kriteria ibu melahirkan anak pertama, berdomisili di kecamatan Gedong Tataan, bayi berusia 2 minggu sampai 1 bulan.

Data penelitian ini diperoleh dengan menggunakan skala model Likert yang terdiri dari skala tingkat stres pasca wanita melahirkan dan skala dukungan sosial. Berdasarkan hasil ujicoba alat ukur, untuk skala tingkat stres ditemukan valid sebanyak 28 item $(r=.3-.731)$. Untuk skala dukungan sosial ditemukan valid sebanyak 35 item $(r=.308-.804)$. Lebih lanjut, terkait reliabilitas, hasil ujicoba menunjukkan kedua skala reliabel, baik untuk skala stress ( $a=$ .816) dan skala dukungan sosial ( $\alpha=.946)$. Data dalam penelitian ini dianalisis menggunakan teknik korelasi Pearson.

Anisa Fitriani, Program Studi Psikologi Islam, Fakultas Usluhuddin dan Studi Agama UIN Raden Intan Lampung. Email: anisa.fitriani@radenintan.ac.id

Indar Nuryati, Program Studi Psikologi Islam, Fakultas Usluhuddin dan Studi Agama UIN Raden Intan Lampung. Email: indar,nuryati@gmail.com 


\section{DUKUNGAN SOSIAL DAN TINGKAT STRES PADA IBU PASCA MELAHIRKAN ANAK PERTAMA}

\section{HASIL}

Setelah dilakukan uji asumsi dasar berupa uji normalitas dan linearitas, ditemukan data terdistribusi normal baik untuk tingkat stress (K$S Z=.670, p>.05)$ maupun dukungan sosial $(\mathrm{K}-\mathrm{S} Z=.512, \mathrm{p}>.05)$ sehingga teknik analisis Pearson dapat dilakukan. Langkah selanjutnya adalah uji hipotesis. Analisis data yang digunakan untuk menguji hipotesis yang diajukan dalam penelitian ini menggunakan teknik korelasi pearson. Perhitungan data dilakukan dengan menggunakan program SPSS. Berdasarkan hasil analisis yang dilakukan ditemukan tidak ada hubungan antara dukungan sosial dengan tingkat stress $(r(31)=$ .238 dengan $p>.05)$.

\section{Tabel 1}

Uji Hipotesis Tingkat Stres, Dukungan Sosial dan Pengetahuan

\begin{tabular}{ll}
\hline Variabel & Tingkat stress \\
\hline Dukungan_sosial & 0,238 \\
\hline $\mathrm{n}=31$ & \\
$\mathrm{p}>.05$ &
\end{tabular}

DISKUSI

Berdasarkan hasil penelitian ini ditemukan tidak ada hubungan antara dukungan sosial dengan tingkat stress pada lbu pasca melahirkan anak pertama $(r(31)=.238$ dengan $p>.05)$. Henshaw (2003) menyatakan tingkat stres ibu pasca melahirkan dipengaruhi oleh dua faktor utama yaitu faktor internal dan eksternal. Faktor internal antara lain, fluktuasi hormonal, faktor psikologis dan kepribadian, adanya riwayat depresi sebelumnya, riwayat kehamilan dan persalinan dengan komplikasi, persalinan section caesarea, kesulitan menyusui, dan minimnya pengetahuan ibu akan perawatan bayi. Sedangkan faktor eksternal meliputi dukungan sosial, kondisi ekonomi, kualitas kesehatan bayi, dan status mental suami. Hasil penelitian ini tidak sejalan dengan pandangan Heenshaw (2003) tersebut bahwa dukungan sosial tidak berhubungan secara signifikan dengan tingkat stres ibu pasca melahirkan.

Berdasarkan hasil ini peneliti berasumsi bahwa tingkat stress ibu lebih dipengaruhi oleh faktor lain yang tidak diteliti

Anisa Fitriani, Program Studi Psikologi Islam, Fakultas Usluhuddin dan Studi Agama UIN Raden Intan Lampung. Email: anisa.fitriani@radenintan.ac.id Indar Nuryati, Program Studi Psikologi Islam, Fakultas Usluhuddin dan Studi Agama UIN Raden Intan Lampung. Email: indar,nuryati@gmail.com 


\section{DUKUNGAN SOSIAL DAN TINGKAT STRES PADA IBU PASCA MELAHIRKAN ANAK PERTAMA}

dalam penelitian ini. Selain dukungan sosial ada faktor-faktor lain yang lebih memiliki hubungan dibandingkan dukungan sosial. Faktor lain yang kemungkinan memiliki hubungan seperti pendapatan ekonomi dari subjek, usia ibu, jenis persalinan, dan pekerjaan dari ibu. Faktor-faktor inilah yang kemungkinan memiliki hubungan antara tingkat stres pada wanita pasca melahirkan anak pertama dibandingkan faktor dukungan sosial dan pengetahuan.

\section{SIMPULAN DAN SARAN}

Berdasarkan hasil penelitian dapat disimpulkan tidak ada hubungan yang signifikan antara dukungan sosial dengan tingkat stres ibu pasca melahirkan anak pertama. Untuk penelitian selanjutnya diharapka dapat meneliti faktor lain yang berhubungan dengan stress pada ibu pasca melahirkan anak pertama, seperti faktor usia, jenis persalinan, dan pekerjaan ibu.

\section{DAFTAR PUSTAKA}

Aprianawati, R. B., \& Sulistyorini, I. R. (2007). Hubungan antara dukungan keluarga dengan kecemasan ibu hamil menghadapi kelahiran anak pertama pada masa triwulan ketiga. Yogyakarta: Universitas Gajah Mada.
Bobak, I. M., Lowdermilk, D. L., \& Jensen, M. D. (2005). Keperawatan Maternitas, Edisi 4. Jakarta: EGC.

Hidayati, R. (2009). Asuhan keperawatan pada kehamilan fisiologis dan patologis. Penerbit Salemba.

Henshaw, C. (2003). Mood Disturbance In The Early Peurperium: A Review, Archives of Women's Mental Helath, 6(2), 33-42.

Indarti, Junita. (2004). Panduan Kesehatan Wanita. Jakarta : Puspa swara.

Kumolohadi, R. (2001). Tingkat stres dosen perempuan UII ditinjau dari dukungan suami. Jurnal Psikologi, 12, 29-42.

Sarafino WP. 2008. Health psychology:biopsychosocial interactions.Canada: JohnWilley \& Son.(OnlineJournal).I

Smet, B. (1994). Psikologi kesehatan.

Sulistyawati, I. (2010). Hubungan antara dukungan sosial dengan self efficacy mahasiswa dalam menyusun skripsi. Jurnal Psikologi Sosial, 1(1), 9-11.

Anisa Fitriani, Program Studi Psikologi Islam, Fakultas Usluhuddin dan Studi Agama UIN Raden Intan Lampung. Email: anisa.fitriani@radenintan.ac.id

Indar Nuryati, Program Studi Psikologi Islam, Fakultas Usluhuddin dan Studi Agama UIN Raden Intan Lampung. Email: indar,nuryati@gmail.com 
Jurnal Psikologi Malahayati, Volume 1, No.2, September 2019: 1-7

\section{DUKUNGAN SOSIAL DAN TINGKAT STRES PADA IBU PASCA MELAHIRKAN ANAK PERTAMA}

Tongko, M. (2018). EFEKTIVITAS HYPNO-EFT

(EMOSIONAL FREEDOM TECHNIQUE)

DALAM MENURUNKAN TINGKAT

STRESS MENGHADAPI PERSALINAN

PADA IBU PRIMIGRAVIDA DI WILAYAH

PUSKESMAS RAWAT INAP BATUI. Jurnal

Kesmas Untika Luwuk: Public Health

Journal, 9(1).

Anisa Fitriani, Program Studi Psikologi Islam, Fakultas Usluhuddin dan Studi Agama UIN Raden Intan Lampung. Email: anisa.fitriani@radenintan.ac.id

Indar Nuryati, Program Studi Psikologi Islam, Fakultas Usluhuddin dan Studi Agama UIN Raden Intan Lampung. Email: indar,nuryati@gmail.com 